\title{
ANALISIS PENGARUH PERTUMBUHAN EKONOMI, PENDIDIKAN, DAN KEMISKINAN TERHADAP PENGANGGURAN DI PROVINSI BALI
}

\section{Ira Dwi Radila, Wiwin Priana, Muhamad wahed}

Universitas Pembangunan Nasional (UPN) Vetera Jawa Timur, Indonesia

Email : iradwiradila12@gmail.com,wiwinpriana10@gmail.com, muhammadwahed124@gmail.com

\begin{tabular}{l}
\hline INFO ARTIKEL \\
\hline Diterima \\
5 Juni 2021 \\
Direvisi \\
8 Juni 2021 \\
Disetujui \\
21 Juni 2021 \\
\hline
\end{tabular}

Keywords: economic growth; education; poverty; and unemployment

\section{ABSTRACT}

This study aims to determine the effect of economic growth (GDP), education, and poverty on unemployment in Provindi Bali in the period 2007 to 2020 using secondary data taken through the website of the Central Bureau of Statistics of Bali Province. The study used multiple linear regression analyses in which economic growth, education, and poverty were free variables, and unemployment as variables were bound. This study uses quantitative approach and the data obtained is analyzed with multiple linear regression analysis with Ordinary Least Square (OLS) model. The study used SPSS to interpret the results. The test results showed that variable economic growth (GDP) had a negative and significant influence on unemployment, educational variables also had a significant negative influence on unemployment, and for variables poverty had no effect on unemployment.

\begin{abstract}
ABSTRAK
Penelitian ini bertujuan untuk mengetahui pengaruh pertumbuhan ekonomi, pendidikan, dan kemiskinan terhadap pengangguran di Provindi Bali pada periode tahun 2007 sampai 2020 dengan menggunakan data sekunder yang diambil melalui website Badan Pusat Statistik Provinsi Bali. Penelitian ini menggunakan analisis regresi linier berganda dimana pertumbuhan ekonomi, pendidikan, dan kemiskinan sebagai variabel bebas, dan pengangguran sebagai variabel terikat. Penelitian ini menggunakan pendekatan kuantitatif dam data yang diperoleh dianalisis dengan analisis regresi linier berganda dengan model Ordinary Least Square (OLS). Penelitian menggunakan SPSS untuk menginterpretasikan hasilnya. Hasil pengujian menunjukkan bahwa variabel pertumbuhan ekonomi (PDRB) memiliki pengaruh negatif dan signifikan terhadap pengangguran, variabel pendidikan juga
\end{abstract} Kata Kunci: 


\begin{tabular}{lll}
\hline pertumbuhan ekonomi; & memiliki pengaruh yang negatif signifikan terhadap \\
pendidikan; kemiskinan; & pengangguran, dan untuk variabel kemiskinan tidak \\
dan pengangguran. & memiliki pengaruh terhadap pengangguran.
\end{tabular}

\section{Pendahuluan}

Indonesia merupakan negara berkembang yang memiliki tujuan untuk mencapai suatu kesejahteraan. Dalam mencapai suatu kesejahteraan, dibutuhkan keseimbangan antara angkatan kerja dan kesempatan kerja, namun yang terjadi di Indonesia jumlah angkatan kerja lebih banyak dari pada kesempatan kerja, hal ini berdampak pada terjadinya kenaikan pengangguran(Sugiharto, 2007). Salah satu penilaian prestasi ekonomi suatu negara harus di lakukan, karena dengan pengukuran prestasi ekonomi dapat diukur keberhasilan pemerintahan yang dijalankan, serta untuk mengetahui tingkat keberhasilan kebijakan makro ekonomi yang dijalankan. Untuk mengukur prestasi makro ekonomi dapat diihat dari indikator ekonomi, salah satunya pengangguran. Pengangguran adalah seseorang yang sudah digolongkan dalam angkatan kerja, yang secara aktif sedang mencari pekerjaan pada suatu tingkat upah tertentu, tetapi tidak dapat memperoleh pekerjaan yang diinginkannya (R. S. H. Sukirno $\&$ Sutarmanto, 2007). Provinsi Bali, angka pengangguran masih terbilang cukup tinggi. Berikut diagram presentasi.

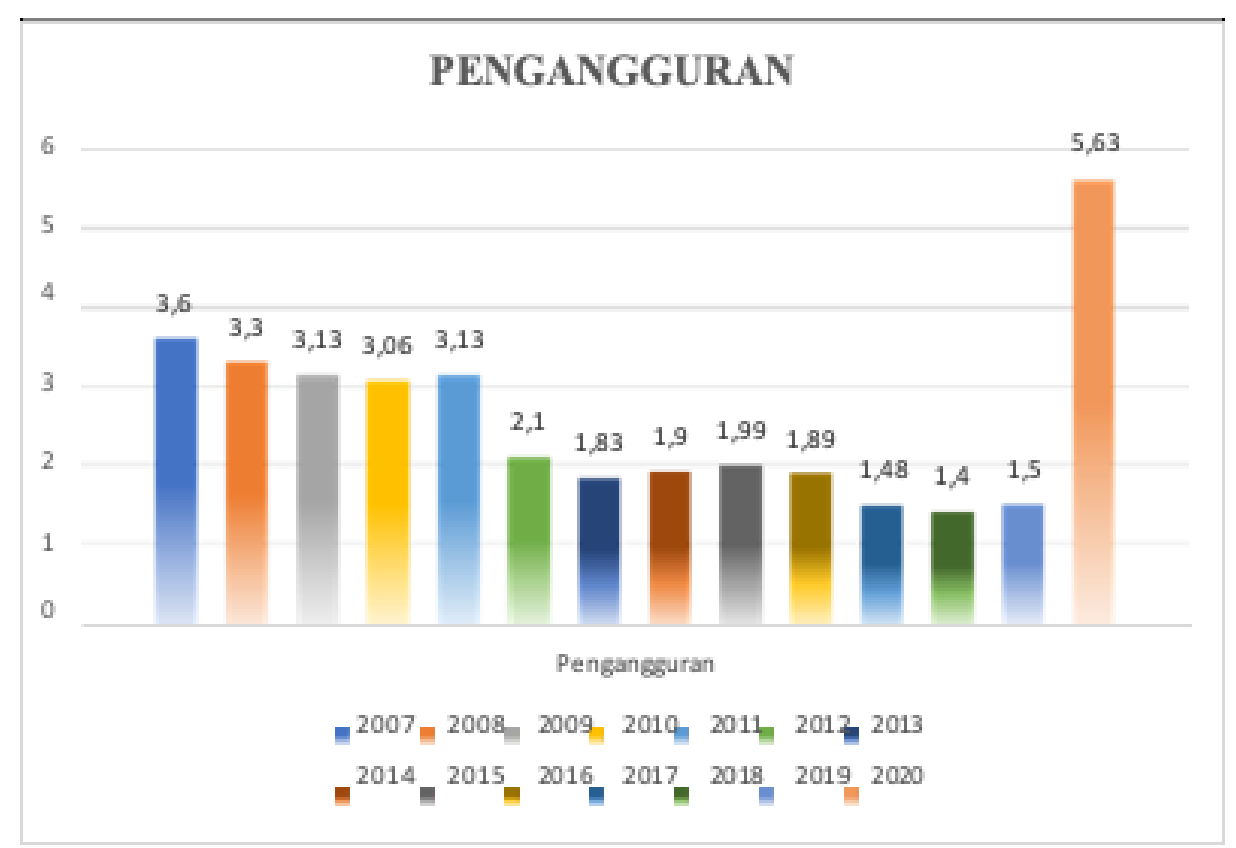

\section{Gambar 1}

\section{Pengangguran Provinsi Bali 2007-2020}

Sumber: BPS Bali 2020 (data diolah)

Pada Gambar 1 diatas dapat dilihat presentase tingkat pengangguran provinsi Bali dalam empat belas tahun terakhir relative mengalami penurunan. Angka terendah pengangguran Bali terjadi di tahun 2018 yakni sebesar 1,4\% sedangkan angka 
penganguran Bali tertinggi terjadi pada tahun 2020 5,63\%. Hal ini terlihat bahwa hasil upaya yang dilakukan pemerintah provinsi Bali dalam rangka menanggulangi pengangguran memperlihatkan hasil yang cukup baik. Namun pada tahun 2020 angka pengangguran naik drastis menjadi 5,63\%. Hal ini menjadi masalah baru yang harus di atasi oleh pemerintah provinsi Bali. Pada tahun 2020 menunjukkan bahwa tingkat pengangguran Bali meningkat sebesar 4,06\%. Menurut BPS Suryamin, bertambahnya angka pengangguran di tahun 2020 disebabkan karena melemahnya pariwisata Bali yang diakibatkan adanya pandemic. Banyaknya faktor yang mempengaruhi tingkat pengangguran antara lain pertumbuhan ekonomi. Hal ini dapat dijelaskan pada gambar 2 berikut ini:

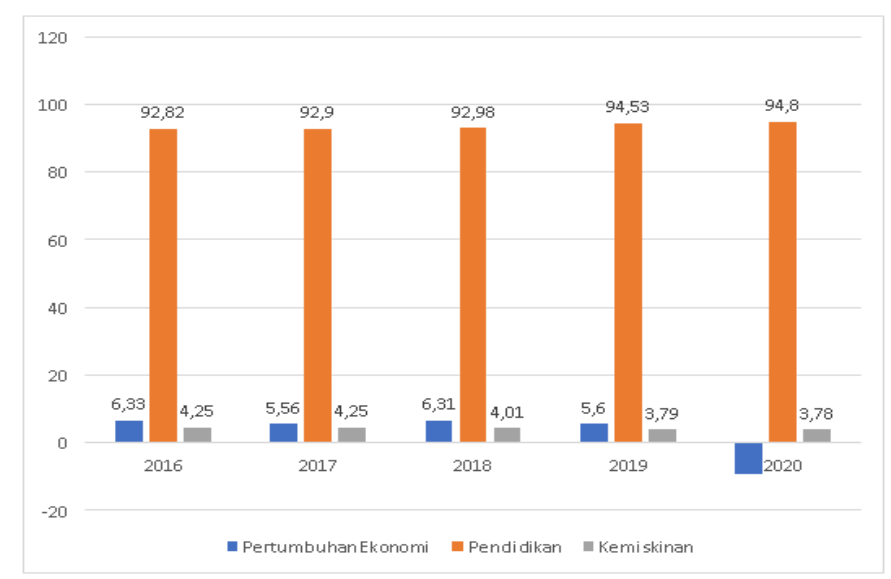

Gambar 2

Pertumbuhan Ekonomi Provinsi Bali 2016-2020

Sumber: BPS Bali 2020 (data diolah)

Dapat dilihat gambar 2 bahwa tingkat pertumbuhan ekonomi provinsi Bali pada lima tahun terakhir cenderung mengalami penurunan disetiap tahunnya dan angka terendah yakni ada pada tahun 2020 yaitu sebesar -9,31\%. Dalam tahun tersebut penurunan terjadi sangat drastis. Dapat disimpulkan bahwa Pertumbuhan Ekonomi Bali selama lima tahun terakhir mengalami fluktuasi turun, dengan adanya laju pertumbuhan ekonomi di Provinsi Bali yang berfluktuatif dari tahun ke tahun. Menurut (Tambunan, 2009) menyatakan penganguran dan pertumbuhan ekonomi memiliki hubungan negatif artinya meningkatnya pertumbuhan ekonomi diimbangi dengan menurunnya tingkat pengangguran di Bali. Hal ini sejalan dengan penelitian (Shafira et al., 2021) mengenai analisis pertumbuhan ekonomi terhadap pengangguran dimana variabel pertumbuhan ekonomi dalam hal ini pertumbuhan ekonomi berpengaruh negatif signifikan terhadap pengangguran.

Faktor kedua yang mempengaruhi pengangguran adalah pendidikan. Pendidikan memiliki peran penting dalam kehidupan berbangsa dan bernegara dalam upaya menciptakan sumber daya manusia yang berkualitas. Menurut Fuad Ihsan (Fuad, 2005) menjelaskan bahwa pendidikan merupakan suatu faktor kebutuhan dasar untuk setiap manusia sehingga upaya mencerdaskan kehidupan bangsa, karena melalui pendidikan 
upaya peningkatan kesejahteraan rakyat dapat diwujudkan. Dapat disimpulkan bahwa tingkat pendidikan provinsi Bali selalu mengalami peningkatan dari tahun 2017 hingga 2020. Apabila pendidikan mengalami peningkatan dapat diduga bahwa tingkat pengangguran akan mengalami pengurangan (S. Sukirno, 2004). Hal ini sejalan dengan penelitian (Susanto et al., 2018) mengenai pengaruh pendidikan terhadap pengangguran dimana hasil penelitian menjelaskan bahwa tingkat pendidikan berpengaruh signifikan terhadap pengangguran.

Bukan hanya faktor pertumbuhan ekonomi dan pendidikan saja yang dapat berpengaruh terhadap tingkat pengangguran di Provinsi Bali. Faktor lain yang juga berpengaruh terhadap tingkat pengangguran adalah kemiskinan. Kemiskinan memiliki hubungan yang sangat erat dalam mempengaruhi tingkat pengangguran. Permasalahan kemiskinan merupakan masalah yang begitu kompleks sehingga diperlukan upaya pengentasan secara komprehensif, mencangkup berbagai aspek kehidupan masyarakat dan dilaksanakan secara terpadu (Prastyo \& EDY YUSUF, 2010).

Tingkat kemiskinan provinsi bali relative mengalami penurunan dan selama lima tahun terakhir. Tingkat kemiskinan terendah terjadi pada tahun 2020 yakni sebesar 3,78 sedangkan tingkat kemiskinan tertinggi terjadi pada tahun 2016 dan 2017. Dalam (Todaro \& Smith, 2003) menjelaskan bahwa tingkat kemiskinan memiliki pengaruh positif artinya ketika kemiskinan turun maka pengangguran juga turun dan sebaliknya.

Berdasarkan pemaparan diatas maka peneliti merasa tertarik untuk meneliti kembali karena adanya perbedaan hasil penelitian sebelumnya mengenai pengangguran serta menjadi motivator utama penulis untuk melakukan penelitian ini. Dimana peneliti mengkaji ulang lebih lanjut tentang analisis pertumbuhan ekonomi, pendidikan dan kemiskinan terhadap penganggguran yang dikaitkan dengan pandemic yang terjadi pada tahun 2020. Berdasarkan latar belakang yang telah diuraikan di atas, maka diperoleh rumusan masalah dalam penelitian ini adalah sebagai berikut: 1) Apakah terdapat pengaruh Pertumbuhan Ekonomi terhadap pengangguran di Provindi Bali?, 2) Apakah terdapat pengaruh pendidikan terhadap pengangguran di Provinsi Bali?, (3) Apakah terdapat pengaruh kemiskinan terhadap pengangguran di Provinsi Bali.

\section{Metode Penelitian}

Pendekatan dalam penelitian ini adalah pendekatan kuantitatif, karena penelitian ini disajikan dengan angka-angka. Hal ini sesuai dengan pendapat (Arikunto 2006:12) dalam (Zulfah, 2017) yang mengemukakan penelitian kuantitatif adalah pendekatan penelitian yang banyak dituntut menguakan angka, mulai dari pengumpulan data, penafsiran terhadap data tersebut, serta penampilan hasilnya. Penelitian ini menggunakan data sekunder yang diambil dari BPS provinsi Bali dengan Periode waktu yang digunakan dalam penelitian ini yaitu data tahun 2007 sampai 2020. Data yang diperoleh dianalisis menggunakan SPSS dengan model regresi linear berganda. Dalam penelitian ini akan membuktikan hubungan kasual antara variabel terikat (dependent) yaitu Pengangguran sedangkan variabel bebas (independent) yaitu, variabel Pertumbuhan ekonomi, Pendidikan, dan Kemiskinan. 
Ira Dwi Radilal, Wiwin Priana, Muhamad wahed

\section{Hasil dan Pembahasan}

1. Uji Asumsi Klasik Uji Multikolinritas

Untuk mendeteksi ada dan tidaknya multikolinieritas didalam model regresi ini yaitu dengan cara melihat nilai tolerance $>0.10$ dan nilai Variance inflation Factor (VIF) < 10 artinya tidak ada multikolinieritas antar variabel independent dalam model regresi (Ghozali, 2018).

\section{Tabel 1}

\section{Uji Multikolinieritas Coeffients ${ }^{\mathrm{a}}$}

\begin{tabular}{|c|c|c|c|c|c|c|}
\hline \multicolumn{2}{|c|}{ Unstandardized Coefficients } & \multirow{2}{*}{$\begin{array}{c}\text { Standardized } \\
\text { Coefficients } \\
\text { Beta }\end{array}$} & \multirow[t]{2}{*}{$t$} & \multirow[t]{2}{*}{ Sig. } & \multicolumn{2}{|c|}{$\begin{array}{l}\text { Collinearity } \\
\text { Statistics }\end{array}$} \\
\hline Model & $\begin{array}{l}\text { Std. } \\
\text { Error }\end{array}$ & & & & Tolerance & VIF \\
\hline 1 (Constant $)$ & 5,361 & & 4,513 & 001 & & \\
\hline $\begin{array}{l}\text { pertumbuhan }-, 279 \\
\text { ekonomi }\end{array}$ &, 021 & $-1,004$ & 13,381 & 000 & ,863 & 1,159 \\
\hline Pendidikan & 051 &,- 573 & $-4,447$ & $\overline{001}$ & 293 & 3,418 \\
\hline Kemiskinan & ,172 & ,079 &, 632 & $\overline{541}$ & ,312 & 3,202 \\
\hline
\end{tabular}

a. Dependent Variable: pengangguran

Dari Tabel 1 menunjukkan bahwa pertumbuhan ekonomi, pendidikan, dan kemiskinan memiliki nilai Tolerance $>0,10$ dan VIF $<10$ maka Tabel 1 dinyatakan bebas dari multikolinearitas untuk variabel pengangguran

1) Ujian Heteroskedastisitas

Uji heteroskedastisitas bertujuan menguji apakah dalam model regresi terjadi ketidaksamaan variance dari residual satu pengamatan ke pengamatan yang lain.

Tabel 2

Uji Heteroskedastisitas

\begin{tabular}{|c|c|c|c|c|c|c|}
\hline & pertumbuhan ekon & $\mathrm{mi}$ & & didikan & kemiskinan & $\begin{array}{c}\text { Unstandar } \\
\text { dized }\end{array}$ \\
\hline $\begin{array}{l}\text { Spearman's } \\
\text { rho }\end{array}$ & pertumbuhan ekonomi & $\begin{array}{l}\text { Correlation } \\
\text { Coefficient }\end{array}$ & 1,000 &,- 156 & ,009 & ,297 \\
\hline & & Sig. (2-tailed) & . & ,594 & ,976 & ,303 \\
\hline & & $\mathrm{N}$ & 14 & 14 & 14 & 14 \\
\hline & Pendidikan & $\begin{array}{l}\text { Correlation } \\
\text { Coefficient }\end{array}$ &,- 156 & 1,000 &,$- 858^{* *}$ & ,090 \\
\hline & & Sig. (2-tailed) & ,594 & . & ,000 & ,759 \\
\hline & & $\mathrm{N}$ & 14 & 14 & 14 & 14 \\
\hline & Kemiskinan & $\begin{array}{l}\text { Correlation } \\
\text { Coefficient }\end{array}$ & ,009 &,$- 858^{* *}$ & 1,000 &,- 035 \\
\hline & & Sig. (2-tailed) & ,976 &, 000 & . & ,905 \\
\hline & & $\mathrm{N}$ & 14 & 14 & 14 & 14 \\
\hline & $\begin{array}{l}\text { Unstandardized } \\
\text { Residual }\end{array}$ & $\begin{array}{l}\text { Correlation } \\
\text { Coefficient }\end{array}$ & ,297 & ,090 &,- 035 & 1,000 \\
\hline & & Sig. (2-tailed) & ,303 &, 759 & ,905 & \\
\hline & & $\mathrm{N}$ & 14 & 14 & 14 & 14 \\
\hline
\end{tabular}

**. Correlation is significant at the 0.01 level (2-tailed).

Sumber: Data sekunder diolah (2021) 
Berdasarkan Tabel 2 menunjukkan pertumbuhan ekonomi, pendidikan, dan kemiskinan memiliki nilai signifikansi > 0,05. Hal ini dapat dikatakan bahwa model ini layak untuk digunakan karena tidak terjadi heteroskedastisitas.

2) Uji Autokolerasi

Cara untuk mendeteksi adanya autokolerasi adalah dengan melihat Durbin Watson dengan ketentuan -2 sampai 2 tidak terjadi autokulorasi maka dapat disimpulkan bahwa penelitian ini tidak terjadi autokolerasi dilihat pada Tabel 3 karena menunjukkan nilai Durbin Watson sebesar 1,939.

Tabel 3

Uji Autokorelasi Model Summaryb

\begin{tabular}{|c|c|c|c|c|c|c|c|c|c|c|}
\hline \multirow[b]{2}{*}{ Model } & \multirow[b]{2}{*}{$\mathrm{R}$} & \multirow[b]{2}{*}{$\begin{array}{c}\mathrm{R} \\
\text { Square }\end{array}$} & \multirow[b]{2}{*}{$\begin{array}{c}\text { Adjusted } \\
R \\
\text { Square }\end{array}$} & \multirow[b]{2}{*}{$\begin{array}{l}\text { Std. Error } \\
\text { of the } \\
\text { Estimate }\end{array}$} & \multicolumn{5}{|c|}{ Change Statistics } & \multirow[b]{2}{*}{$\begin{array}{l}\text { Durbin- } \\
\text { Watson }\end{array}$} \\
\hline & & & & & $\begin{array}{c}\mathrm{R} \\
\text { Square } \\
\text { Change }\end{array}$ & $\begin{array}{c}\mathrm{F} \\
\text { Change }\end{array}$ & df1 & df2 & $\begin{array}{l}\text { Sig. F } \\
\text { Change }\end{array}$ & \\
\hline 1 & $975^{\mathrm{a}}$ & ,951 & ,937 & ,29076 & ,951 & 65,262 & 3 & 10 &, 000 & 1,939 \\
\hline
\end{tabular}

a. Predictors: (Constant), kemiskinan, pertumbuhan ekonomi, pendidikan

b. Dependent Variable: pengangguran

Sumber: Data sekunder diolah (2021)

3) Analisis regresi linear berganda

Analisis regresi linier berganda digunakan untuk mengetahui adanya pengaruh pertumbuhan ekonomi, pendidikan, dan kemiskinan terhadap pengangguran. Berikut hasil analisis regresi linier berganda dalam penelitian ini dapat dilihat pada tabel berikut:

Tabel 4

Analisis Regresi Linier Berganda Coefficientsa

\begin{tabular}{|c|c|c|c|c|c|c|}
\hline \multirow{2}{*}{\multicolumn{2}{|c|}{ Model }} & \multicolumn{2}{|c|}{$\begin{array}{c}\text { Unstandardized } \\
\text { Coefficients }\end{array}$} & \multirow{2}{*}{$\begin{array}{l}\text { Standardized } \\
\text { Coefficients } \\
\text { Beta }\end{array}$} & \multirow[b]{2}{*}{$\mathbf{t}$} & \multirow[b]{2}{*}{ Sig. } \\
\hline & & B & Std. Error & & & \\
\hline \multirow[t]{4}{*}{1} & (Constant $)$ & 24,193 & 5,361 & & 4,513 & 001 \\
\hline & $\begin{array}{l}\text { pertumbuhan } \\
\text { ekonomi }\end{array}$ &,- 279 & ,021 & $-1,004$ & $-13,381$ & ,000 \\
\hline & Pendidikan &,- 228 & ,051 &,- 573 & $-4,447$ & ,001 \\
\hline & Kemiskinan & , 108 &, 172 & ,079 & 632 & ,541 \\
\hline
\end{tabular}

a. Dependent Variable: pengangguran

Sumber: Data sekunder diolah (2021)

Berdasarkan Tabel 4, diperoleh persamaan regresi sebagai berikut:

Pengangguran $=224,193-0,279$ Pertumbuhan ekonomi $-0,228$ Pendidikan -

$$
\text { 0,108Kemiskinan }+\mathrm{e}
$$

2. Uji Kelayakan Model

a. Uji Koefisien Determinasi (R2)

Koefisien determinasi (R2) pada intinya seberapa jauh dalam mengukur kemampuan model yang menerangkan variabel dependen. Hasil koefisien determinasi pada Tabel 5 . 
Tabel 5

Uji Koefisien

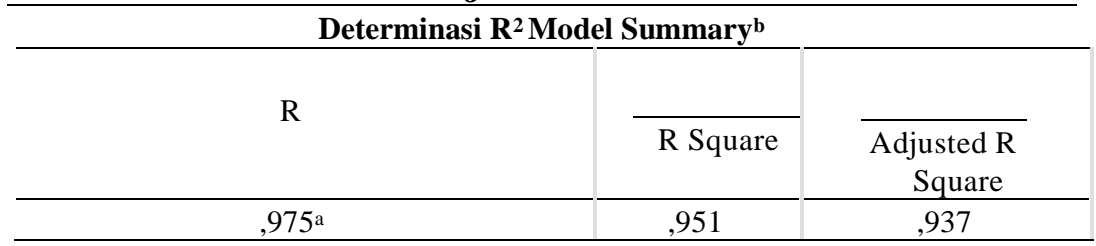

a. Predictors: (Constant), kemiskinan, pertumbuhan ekonomi, pendidikan

b. Dependent Variable: pengangguran

Berdasarkan Tabel 5 menunjukkan bahwa nilai koefisien determinasi sebesar yang terdapat dikolom $\mathrm{R}$ square sebesar 0,951 atau 95,1\% untuk pertumbuhan ekonomi, pendidikan, dan kemiskinan dan sisanya dijelaskan oleh variabel lain diluar model.

b. Uji F

Pengujian ini bertujuan untuk menguji apakah model (sesuai) fit atau tidak (Ghozali, 2018). Uji F dilakukan dengan melihat signifikansi F pada output hasil regresi dengan signifikansi $0,05(\mathrm{a}=5 \%)$. Berdasarkan Tabel 6 menunjukkan bahwa nilai $\mathrm{F}$ hitung sebesar 65,262 dengan nilai signifikansi 0,000 sehingga model ini layak untuk digunakan.

Tabel 6

Uji Statistik F ANOVAa

\begin{tabular}{lrr|r|r|r|r}
\hline Model & Sum of Squares & \multicolumn{1}{c|}{$\boldsymbol{d f}$} & Mean Square & F & \multicolumn{1}{c}{ Sig. } \\
\hline 1 & 16,552 & 3 & 5,517 & 65,262 &, $000^{\mathrm{b}}$ \\
\cline { 2 - 7 } & Regression &, 845 & 10 &, 085 & & \\
\cline { 2 - 8 } & Residual & 17,398 & 13 & & & \\
\cline { 2 - 6 } & Total & & & &
\end{tabular}

a. Dependent Variable: pengangguran

b. Predictors: (Constant), kemiskinan, pertumbuhan ekonomi, pendidikan

Sumber: Data sekunder diolah (2021)

c. Uji Hipotesis (Uji t)

Uji t dilakukan dengan melihat signifikansi t masing-masing variabel pada output hasil regresi dengan signifikansi $0,05(\mathrm{a}=5 \%)$. Kriteria pengambilan keputusannya adalah jika hasil signifikansi > 0,05 maka hipotesis ditolak (koefisien regresi tidak signifikan) dan sebaliknya. Hasil pengujian dari hipotesis terhadap nilai signifikansi dapat disajikan dalam Tabel 7.

Tabel 7

Hasil Pengujian Hipotesis Coefficientsa

\begin{tabular}{|c|c|c|c|c|c|c|}
\hline \multirow[b]{2}{*}{ Model } & \multicolumn{3}{|c|}{$\begin{array}{c}\text { Unstandardized } \\
\text { Coefficients }\end{array}$} & \multirow{2}{*}{$\begin{array}{c}\text { Standardized } \\
\text { Coefficients } \\
\text { Beta } \\
\end{array}$} & \multirow[b]{2}{*}{$\mathrm{t}$} & \multirow[b]{2}{*}{ Sig. } \\
\hline & & B & Std. Error & & & \\
\hline \multirow[t]{3}{*}{1} & (Constant) & 24,193 & 5,361 & & 4,513 & ,001 \\
\hline & $\begin{array}{l}\text { pertumbuhan } \\
\text { ekonomi }\end{array}$ &,- 279 & 021 & $-1,004$ & $-13,381$ & ,000 \\
\hline & Pendidikan &,- 228 & 051 &,- 573 & $-4,447$ & ,001 \\
\hline
\end{tabular}


Analisis Pengaruh Pertumbuhan Ekonomi, Pendidikan, dan Kemiskinan terhadap Pengangguran Di Provinsi Bali

\begin{tabular}{rr|r|r|r|r}
\hline Kemiskinan &, 108 &, 172 &, 079 &, 632 &, 541 \\
\hline
\end{tabular}

a. Dependent Variable: pengangguran

Sumber: Data sekunder diolah (2021)

Berdasarkan Tabel 7 diperoleh hasil perhitungan $\mathrm{t}$ berserta tingkat signifikansi dengan penjelasan sebagai berikut: 1 . Uji pengaruh pertumbuhan ekonomi terhadap pengangguran memiliki t hitung sebesar -13,381 dengan nilai signifikansi 0,000, maka dapat disimpulkan bahwa pertumbuhan ekonomi berpengaruh negatif dan signifikan terhadap pengangguran. 2. Uji pengaruh pendidikan terhadap pengangguran memiliki t hitung sebesar -4,447 dengan nilai signifikansi 0,001, maka dapat disimpulkan bahwa pendidikan berpengaruh negative dan signifikan terhadap pengangguran. 3. Uji pengaruh kemiskinan terhadap pengangguran memiliki t hitung sebesar 0,632 dengan nilai signifikansi 0,541, maka dapat dikatakan bahwa kemiskinan tidak berpengaruh terhadap pengangguran.

3. Pengaruh pertumbuhan ekonomi terhadap Pengangguran

Berdasarkan hasil pengujian pada tabel 7 , pengaruh pertumbuhan ekonomi terhadap pengangguran menghasilkan nilai koefisien (standardized coefficient) negatif sebesar -1,004 dengan signifikansi value sebesar 0,000. Oleh karena itu, sig value $0,000<\operatorname{sig}$ itolerance 0,05 , maka hipotesis satu diterima, karena pengaruh pertumbuhan ekonomi terhadap pengangguran terbukti signifikan. Pertumbuhan ekonomi merupakan salah satu indikator yang dalam menilai kinerja suatu perokonomian, terutama untuk melakukan analisis tentang hasil pembangunan ekonomi yang telah dilaksanakan suatu negara atau suatu daerah. Ekonomi dikatakan mengalami pertumbuhan apabila produksi barang dan jasa meningkat dari tahun sebelumnya. Pertumbuhan ekonomi menunjukkan sejauh mana aktivitas perekonomian yang dapat menghasilkan tambahan pendapatan atau kesejahteraan masyarakat pada periode tertentu. Pertumbuhan ekonomi suatu negara atau suatu wilayah yang terus menunukkan suatu peningkatan menggambarkan bahwa perkonomian negara atau wilayah tersebut berkembang dengan baik. Sebaliknya apabila perekonomian tersebut tidak dapat berkembang dengan baik hal terburuk yang akan muncul adalah masalah pengangguran. Hasil penelitian ini sejalan dengan hasil dari penelitian menurut Syurifto (2018) dalam (Zubaidi et al., 2020) yang menunjukkan bahwa pertumbuhan ekonomi berpengaruh negative dan signifikan terhadap pengangguran.

4. Pengaruh Pendidikan terhadap Pengangguran

Berdasarkan hasil pengujian pada tabel 7, pengaruh pendidikan terhadap pengangguran menghasilkan nilai koefisien (standardized coefficient) negatif sebesar $-0,573$ dengan signifikansi value sebesar 0,001 . Oleh karena itu, sig value $0,001<$ sig itolerance 0,05, maka hipotesis dua diterima, karena pengaruh pendidikan terhadap pengangguran terbukti signifikan. Pendidikan merupakan salah satu hal yang sangat penting untuk anak-anak Indonesia. Sampai sekarang, masih banyak orang tua yang 
masih tidak memperdulikan Pendidikan anak-anaknya. Walaupun pemerintah telah memberikan fasilitas yang cukup umtuk anak mendapatkan Pendidikan, tetap saja ada yang tidak mengindahkannya.

Pendidikan memiliki peran penting dalam kehidupan berbangsa dan bernegara dalam upaya menciptakan sumber daya manusia yang berkualitas. Pendidikan merupakan merupakan faktor kebutuhan dasar untuk setiap manusia sehingga upaya mencerdaskan kehidupan bangsa, karena melalui Pendidikan upaya meningkatan kesejahteraan rakyat dapat diwujudkan. Pedidikan mempengaruhi secara penuh pertumbuhan ekonomi suatu negara atau daerah hal ini bukan saja karena pendidikan akan berpengaruh terhaap produktivitas, tetapi juga akan berpengaruh vertilitas masyarakat. Pendidikan dapat menjadikan sumberdaya manusia lebih cepat mengerti dan siap mengahdapi perubahan dan pembangunan suatu negara. Kegiatan ekonomi di masyarakat membutuhkan tenaga kerja. Kebutuhan akan tenaga kerja ini dapat juga disebut sebagai kesempatan kerja. Kesempatan kerja itu sendiri adalah suatu keadaan yang menggambarkan terjadinya lapangan kerja (pekerjaan) untuk diisi pencari kerja. Hasil dari penelitian ini sejalan dengan penelitian menurut (Indrayeni et al., 2019) bahwa pendidikan berpengaruh signifikan terhadap pengangguran.

5. Pengaruh Kemiskinan terhadap Pengangguran

Berdasarkan hasil pengujian pada tabel 7, pengaruh kemiskinan terhadap pengangguran menghasilkan nilai koefisien (standardized coefficient) positif sebesar 0,079 dengan signifikansi value sebesar 0,541 . Oleh karena itu, sig value 0,541 > sig itolerance 0,05, maka hipotesis tiga ditolak, karena pengaruh kemiskinan terhadap pengangguran terbukti tidak berpengaruh signifikan. Efek buruk dari pengangguran yaitu ketiadaan pendapatan yang menyebabkan para pengangguran harus mengurangi pengeluaran konsumsinya. Pengangguran yang berkepanjangan dapat menimbukan efek psikologis yang buruk atas diri penganggur dan keluarganya. Apabila keadaan pengangguran disuatu negara sangat buruk akibatnya masyarakat miskin semakin bertambah jumlahnya serta mengakibatkan kekacauan politik dan sosial yang berlaku yang menimbulkan efek yang buruk bagi kesejahteraan masyarakat dan prospek pembangunan ekonomi dalam jangka panjang. Perintah eharusnya mengatasi masalah tersebut dengan membuka lapangan pekerjaan sehingga dampak dari masalah pengangguran dapat teratasi, karena tingkat pengangguran juga memberikan kontribusi yang amat besar terhadap meningkatnya jumlah penduduk miskin. Hasil dari penelitian ini sejalan dengan penelitian yang dilakukan oleh (Sriyanah \& Riska, 2021) bahwa kemiskinan tidak signifikan terhadap tingkat pengangguran terbuka.

\section{Kesimpulan}

Berdasarkan hasil dan pembahasan yang ada, dapat diperoleh simpulan bahwa hasil dari penelitian menunjukkan bahwa pertumbuhan ekonomi berpengaruh negative dan signifikan terhadap pengangguran maka dapat disimpulkan bahwa H1 diterima, hasil dari penelitian menunjukkan bahwa pendidikan berpengaruh negative dan signifikan terhadap pengangguran maka dapat disimpulkan bahwa $\mathrm{H} 2$ diterima, hasil 
Analisis Pengaruh Pertumbuhan Ekonomi, Pendidikan, dan Kemiskinan terhadap Pengangguran Di Provinsi Bali

dari penelitian menunjukkan bahwa kemiskinan tidak berpengaruh terhadap pengangguran maka dapat disimpulkan bahwa $\mathrm{H} 3$ ditolak. 
Ira Dwi Radilal, Wiwin Priana, Muhamad wahed

\section{BIBLIOGRAFI}

Fuad, I. (2005). Dasar-dasar pendidikan. Jakarta: PT Rineka Cipta.Google Scholar

Indrayeni, S., Hakim, N., \& Burhanudin, D. (2019). Kemampuan Menulis Pantun Siswa Kelas VII SMP Negeri 2 Lirik. JURNAL TUAH: Pendidikan Dan Pengajaran Bahasa, 1(1), 69-77.Google Scholar

Prastyo, A. A., \& EDY YUSUF, E. Y. (2010). Analisis Faktor-Faktor Yang Mempengaruhi Tingkat Kemiskinan (Studi Kasus 35 Kabupaten/Kota Di Jawa Tengah Tahun 2003-2007. Universitas Diponegoro.Google Scholar

Shafira, V. A., Kumenaung, A. G., \& Niode, A. O. (2021). Analisis Pengaruh Ump, Pertumbuhan Ekonomi Dan Inflasi Terhadap Tingkat Pengangguranterbuka Di Kota Manado. Jurnal EMBA: Jurnal Riset Ekonomi, Manajemen, Bisnis Dan Akuntansi, 9(1).Google Scholar

Sriyanah, N., \& Riska, A. (2021). Edukasi Etika Batuk Efektif di Era New Normal Pandemi Covid-19 Di Desa Solonsa Kecamatan Wita Ponda Kabupaten Morowali. Jurnal Pengabdian Masyarakat Gerakan Aksi Sehat (GESIT), 2(1), 29-35.Google Scholar

Sugiharto, E. (2007). Tingkat Kesejahteraan Masyarakat Nelayan Desa Benua Baru Ilir Berdasarkan Indikator Badan Pusat Statistik. Jurnal Ekonomi Pembangunan Dan Perencanaan, 4(2), 32-36.Google Scholar

Sukirno, R. S. H., \& Sutarmanto, H. (2007). Faktor-faktor yang mempengaruhi intensi membeli produk wayang kulit pada masyarakat suku Jawa. Psikologika: Jurnal Pemikiran Dan Penelitian Psikologi, 12(24), 119-132.Google Scholar

Sukirno, S. (2004). Makro ekonomi teori pengantar edisi ketiga. Jakarta: Raja Grafindo Persada.Google Scholar

Susanto, E., Rochaida, E., \& Ulfah, Y. (2018). Pengaruh inflasi dan pendidikan terhadap pengangguran dan kemiskinan. Inovasi, 13(1), 19-27.Google Scholar

Tambunan, T. T. H. (2009). SMEs in Asian developing countries. Springer.Google Scholar

Todaro, M., \& Smith, S. (2003). Development economics. UK: Pearson Education.Google Scholar

Zubaidi, N., Pratama, R. G., \& Al-Fatih, S. (2020). Legal Perspective on Effectiveness of Pre-Work Cards for Indonesian People. BESTUUR, 8(1), 9-18.Google Scholar

Zulfah, Z. (2017). Analisis Kesalahan Peserta Didik pada Materi Persamaan dan Pertidaksamaan Nilai Mutlak Linear Satu Variabel di Kelas X SMA Negeri 1 Bangkinang Kota. Lemma, 3(2), 232874.Google Scholar 
Analisis Pengaruh Pertumbuhan Ekonomi, Pendidikan, dan Kemiskinan terhadap Pengangguran Di Provinsi Bali

\section{Copyright holder :}

Ira Dwi Radilal, Wiwin Priana, Muhamad wahed (2021)

First publication right:

Jurnal Syntax Admiration

This article is licensed under:

(c) ${ }_{\mathrm{EY}} \ominus_{\mathrm{ND}}$ 